\title{
PENERAPAN IOT (INTERNET OF THING) SMART FLOWER CONTAINER PADA TANAMAN HIAS AGLAONEMA BERBASIS ARDUINO
}

\author{
Sudrajad Dwi Sasmita, Suryo Adi Wibowo, Renaldi Primaswara Prasetya \\ Program Studi Teknik Informatika S1, Fakultas Teknologi Industri \\ Institut Teknologi Nasional Malang, Jalan Raya Karanglo km 2 Malang, Indonesia \\ sudrajad.dwi@gmail.com
}

\begin{abstract}
ABSTRAK
Semasa pandemi covid-19 masyarakat banyak mencari kesibukan untuk mengisi kegiatan selama Work from Home (WFH). Salah satu kegiatan yang dilakukan adalah dengan budidaya tanaman hias Aglaonema, tanaman ini dapat tumbuh dengan baik pada suhu $20^{\circ} \mathrm{C}-23^{\circ} \mathrm{C}$, intesitas cahaya antara 807,293lux - 2152,78lux dan kelembaban udara lebih dari 50\% serta kelembaban tanah lebih dari 50\%. Dari segi perawatan kadang pemilik kurang memperhatikan kondisi lingkungan dari tanaman. Oleh karena itu, dikembangkanlah Sistem Otomatisasi perawatan tanaman Aglaonema berbasis IoT yang bertujuan untuk mempermudah pecinta tananaman hias Aglaonema dalam perawatan tanaman. Metode yang digunakan pada penelitian ini adalah metode pengembangan dan dikembangkan dalam skala 1:2. Fitur pada IoT yang dirancang adalah sistem monitoring berupa monitoring sensor via web dan telegram, sistem otomatisasi untuk pengendali kelembaban tanah dan udara, serta sistem keamanan jika terjadi tindak pencurian tanaman yang dapat dimonitoring via telegram dan web. Dari hasil penelitian menunjukan bahwa sensor dan modul memiliki nilai error dan akurasi, Adapun seperti sensor BH1750 memiliki nilai error rata-rata 4.0\% dan akurasi 96.0\%, sensor DHT22 memiliki nilai error rata-rata 5.0\% dan akurasi 95.0\%, sensor PH memiliki nilai error rata-rata 5.8\% dan akurasi $94.2 \%$, modul Neo-6M memiliki nilai error rata-rata 1\% dan akurasi 99\%, sensor Kelembaban Tanah memiliki nilai error rata-rata $0.4 \%$ dan akurasi $99.6 \%$. dengan demikian IoT yang dikembangkan memiliki akurasi pembacaan nilai sensor dengan cukup baik.
\end{abstract}

Kata Kunci : aglaonema, monitoring, keamanan, neo-6m

\section{PENDAHULUAN}

Pada era pandemi covid -19 seperti saat ini banyak sekali masyarakat yang melakukan WFH (Work From Home), hal ini membuat masyarakat menjadi memiliki banyak waktu luang di rumah, dan pada akhirnya muncul trend baru masyarakat pada era pandemi, di antaranya adalah berkebun atau bercocok tanam tanaman hias. Tanaman Aglonema adalah salah satu tanaman hias yang di minati saat pandemi, hal itu menjadikan tanaman ini di buru kolektor atau pecinta tanaman hias. Pada umumnya tempat menaman tanaman hias Aglaonema berada di dalam pot. Aglaonema merupakan tumbuhan yang sensitif, oleh karena itu memerlukan perhatian khusus dalam perawatannya. Faktor yang mempengaruhi pertumbuhan Aglaonema antara lain adalah intensitas cahaya matahari, temperature ruangan, kelembaban udara, dan ph tanah.

Untuk perawatan harian Aglaonema, pemilik harus melakukan penyiraman manual setiap pagi dan sore hari dalam hal ini pencinta tanaman hias memerlukan waktu ekstra, serta intensitas cahaya dan suhu ruangan juga harus di awasi setiap saat, tanaman aglaonema harus mendapat sinar matahari dan suhu ruangan yang cukup tidak boleh berlebihan atau kekurangan. Untuk pemberian pupuk, tanaman Aglaonema cukup di beri pupuk seminggu sekali. Setiap hari tanaman Aglaonema harus mendapat cahaya matahari yang cukup dengan kadar intensitas cahaya sekitar 10 - $30 \%$ dengan suhu $20^{\circ} \mathrm{C}-30^{\circ} \mathrm{C}$. Untuk kelembaban udara, tanaman Aglaonema membutuhkan sekitar 50- 60\%, dan kelembaban tanah lebih dari sama dengan $50 \%$ jika hal tersebut tidak terpenuhi maka dapat membuat tumbuhan layu. Untuk ph yang di butuhkan tanaman Aglaonema sama seperti tanaman pada umumnya yaitu ph sebesar 7-7,5.

Dengan demikian dalam penelitian ini dibubtuhkanlah sensor suhu dan kelembaban udara, ph tanah, kelembaban tanah, intensitas cahaya, serta modul gps yang di gunakan untuk monitoring keadaan lingkunagan tanaman dan system keamanan.

\section{TINJAUAN PUSTAKA}

\subsection{Penelitian Terdahulu}

Tareh Rozzaq Adzdziqri, dkk (2021) penelitian dengan judul "Implementasi Iot (Internet Of Things) Pada Rumah Budidaya Jamur Tiram Putih". Tujuan melakukan penelitian ini adalah untuk mempermudah monitoring jarak jauh pada budidaya rumah jamur dengan fan dc sebagai aktuator untuk menurunkan suhu, heather sebagai aktuator untuk menaikan suhu, lalu humidifier untuk meningkatkan kelembapan udara, 2 pompa air yang berisikan kapur dan cuka untuk mengatur kadar $\mathrm{pH}$, dan 2 pompa air lagi untuk mengisi kembali air kapur dan cuka jika pada wadah sebelumnnya sudah habis. [1] 
Miko Andrianto (2019) penelitian dengan judul "Penerapan Iot Pada Perawatan Tanaman Di Dalam Rumah". Tujuan dari penelitian ini adalah meminimalisasi perawatan pada tanaman di dalam rumah dengan menginplementasikan system pemantauan intensitas cahaya, kelembaban tanah dengan penerapan internet of things berbasis website, serta memanfaatkan fuzzy logic, yang di gunakan untuk meminimalisir kesalahan pada sistem. [2]

Desvianty Ayu Wahyudi, dkk (2021) penelitian dengan judul "Rancang Bangun Sistem Padi Aquaponic Berbasis Iot (Internet of Things)". Tujuan dari penelitian ini adalah mempermudah petani padi aquaponic untuk memonitoring keadaan dari aliran pompa air, kelembaban tanah, kekeruhan air kolam dan pengendalian hama padi, dengan menggunakan system berbasis IoT (Internet of Things) yang memiliki kelebihan dapat memonitoring dari jarak jauh. [3]

Shaifany Fatriana Kadir (2019) penelitian dengan judul "Mobile Iot (Internet of Things) Untuk Pemantauan Kualitas Air Habitat Ikan Hias Pada Akuarium Menggunakan Metode Logika Fuzzy". Tujuan dari penelitian ini adalah untuk memonitoring kualitas air pada akurium ikan hias. Pengujian sistem dilakukan dengan menggunakan sensor ds18b20 untuk mengukur suhu air, sensor turbidity untuk mengukur kekeruhan air, sensor $\mathrm{pH}$ untuk mengukur keasaman air, dan sensor infrared untuk pendeteksian pakan. Nilai hasil monitoring akan di olah dengan logika fuzzy dan hasil dari perhitungan di gunakan untuk mengatur kecepatan pompa. [4]

Joseph Dedy Irawan, dkk (2016), "Pengembangan Kunci Elektronik Menggunakan RFID Dengan Sistem Iot". Tujuan dari penelitian ini adalah membantu pemilik rumah untuk meningkatkan keamanan rumah, untuk mencegah tamu yang tidak di undang masuk. System keamanan ini menggunakan RFID untuk automatisasi dan system IoT untuk monitoring data, sehingga dengan adanya system ini pemilik rumah dapat mengetahui siapa saja yang masuk ke dalam rumah. Dalam penelitian ini hal pendukung untuk penelitian yang saya buat adalah sama-sama berbasis IoT. [5]

Wahyu Adi Prayitno, dkk (2017), "Sistem Monitoring Suhu, Kelembaban, dan Pengendali Penyiraman Tanaman Hidroponik menggunakanBlynk Android". Tujuan dari penilitian ini adalah Agar pemilik tanaman hidroponik tetap dapat merawat dan memantau kondisi lingkungan tanamannya meskipun jauh dari lokasi penanaman. Dengan menggunakan arduino mega sebagai sistem akuisisi data yang di lengkapi ethernet shielduntuk pengiriman data melalui jaringan internet, sensor DHT11untuk membaca suhu dan kelembaban, aplikasi khusus android blynk sebagai alat bantu pemantuan, dan RTC untuk pewaktuan secara real time. [6]

\subsection{Internet of Things (IoT)}

Internet of Things (IoT) adalah konsep komputasi tentang objek sehari-hari yang terhubung ke internet dan mampu mengidentifikasi diri ke perangkat lain. Penggunaan IoT dapat di terapkan ke pada berbagai hal antara lain adalah pada bidang peternakan, perikanan, pertanian dan sebagainya yang dapat saling bertukar data. Perkembangan IoT dapat di lihat mulai dari tingkat konvergensi teknologi nirkabel, microelectromechanical (MEMS), internet, dan QR (Quick Responses) Code. IoT juga sering di identifikasi dengan RFID (Radio Frequency Identification) sebagai metode komunikasi.

\subsection{Arduino UNO R3}

Arduino Uno R3 adalah mikrokontroler yang menggunakan chip ATmega328P, terkadang terdapat pula Arduino Uno clone yangsering kita jumpai pada pasaran sebagai opsi pengganti Arduino Uno yang menggunakan chip CH340. Arduino Uno R3 memiliki 14 digital pin Input/Output (dengan 6 pin PWM), 6 pin input analog, koneksi USB type A, DC in $5 \mathrm{v}-12 \mathrm{v}$, header ICSP dan tombol reset.

\subsection{Neo-6m}

Neo-6m adalah salah satu modul dari micro controller yang digunakan untuk mengambil nilai latitude dan longitude dari satelite. Dengan Modul GPS neo-6m ini maka kita dapat mengetahui lokasi suatu koordinat di mana modul GPS itu berada, dengan begitu modul tersebut kita dapat digunaka untuk membuat alat pelacakan.

\subsection{Sensor $\mathbf{P H}$}

Sensor PH adalah sensor merupakan modul untuk mendeteksi $\mathrm{pH}$, di mana keluarannya berupa tegangan analog. Dari nilai analog tersebut hasil outputan sensor harus di konversi kedalam nilai PH dengan menggunakan perhitungan matematis

\subsection{DFPlayer mini}

DFPlayer Mini merupakan module pemutar file audio. File yang support pada module ini diantaranya adalah file berformat mp3. DFPlayer mini ini terhubung ke Arduino dengan menggunakan komunikasi serial, dari modul ini akan langsung di hubungkan ke pengeras suara seperti speaker.

\subsection{NodeMCU}

NodeMCU adalah microcontroller yang memiliki firmware LUA dan di khususkan untuk penggunaan project IoT, firmware Node MCU berjalan di dalam chipset ESP8266. Sampai sekarang ada 3 versi NodeMCU yaitu NodeMCU V1, dan V2 adapun yang V3 itu merupakan versi refresh dari V2. NodeMCU memiliki 17 pin input/output, tombol reset dan tombol flash. 


\subsection{Relay}

Relay adalah saklar yang cara kerjanya berdasarkan prinsip elektromaknetik, relay di gunakan untuk penyambung dan pemutus airan listrik, pada Arduino modul relay digunakan untuk penyambung dan pemutus hubungan listrik seperti pada project lampu otomatis, terhubung dan terputusnya relay di sebabkan oleh induksi magnetic dari kontaktor.

\subsection{Hunidifire}

Humidifier adalah alat yang di gunakan untuk mengkabutkan air, pengkabutan air di sebabkan dari humidifier yang menggetarkan permukaan air dengan menggunakan gelombang ultrasonic, dengan begitu air akan terpercik tapi dengan ukuran percikan yang sangat kecil, sehingga akan menggumpal dan menghasilkan kabut.

\subsection{Water Pump 5V}

Water Pump / pompa air adalah alat untuk memompa air dari tempat yang memiliki rendah ke tempat tekanan tinggi. Pada dasarnya waterpump sama dengan motor dc pada umumnya, tetapi sudah di modifikasi sedemikian rupa sehingga dapat di mejadi tahan air.

\subsection{DHT22}

DHT22 merupakan sensor suhu dan kelembaban, sama seperti DHT 11, yang membedanakan sensor tersebut adalah terdapat pada rentan suhu, jika DHT11 dapat membaca suhu dengan rentan $0^{\circ} \mathrm{C}-50^{\circ} \mathrm{C}$ maka DHT22 dapat membaca suhu dengan rentan $-40^{\circ} \mathrm{C}-80^{\circ} \mathrm{C}$, jadi rentan pengukurannya suhu lebih lebar. Demikian dengan kelembaban DHT22 dapat membaca kelembaban dengan rentan $0-100 \%$.

\subsection{BH1750}

BH1750FVI adalah sebuah IC sensor yang di gunakan untuk mengukur intensitas cahaya sekitar dalam ukuran atau satuan lux. Sensor ini menggunakan protokol I2C untuk komunikasi dengan mikrokontroller atau minimum sistem.

\subsection{LCD 16x2 i2c}

LCD $16 \times 2$ i2c adalah lcd yang dbiasanya di gunakan untuk penampil data dar microcontroller, sebenarnya lcd 12x6 memiliki 16 pin, tapi dengan adanya modul i2c dari 16 pin tersebut di ringkas menjadi 4 pin diantaranya adalah sda, scl, gnd, dan vcc. Dengan demikian lcd dapat diakses hanya dengan kita menghubungkannya melalui socket i2c.

\section{METODE PENELITIAN}

\subsection{Kebutuhan Fungsional}

Pada sistem monitoring ini memiliki kebutuhan fungsional diantara lainya sebagai berikut:

1. Sistem yang dibuat dapat memantau PH tanah dari media tanam Aglaonema yang dibaca melalui sensor.

2. Sistem yang dibuat dapat memantau Kelembapan udara dari media tanam Aglaonema yang dibaca melalui sensor.

3. Sistem yang di buat dapat memantau Suhu udara dari media tanam Aglaonema yang dibaca melalui sensor.

4. Sistem yang dibuat dapat memantau intensitas cahaya dari media tanam Aglaonema yang dibaca melalui sensor.

5. Sistem yang dibuat dapat memberikan peringatan pada pengguna jika parameter lingkungan tidak memenuhi kriteria yang dideteksi melalui sensor.

6. Website yang dibuat akan memberikan informasi keadaan lingkungan disekitar tanaman aglaonema kepada user.

7. Feature keamanan pada sistem monitoring akan memberitahu lokasi tanaman jika terjadi kasus pencurian tanaman.

\subsection{Kebutuhan Nonfungsional}

Adapun beberapa kebutuhan nonfungsional dalam system monitoring ini adalah:

1. Alat beserta website membuthkan koneksi jaringan internet.

2. Alat dapat di akses memlalui website secara realtime.

3. Website dapat di akses menggunakan browser seperti Google Chrome, Mozila Firefox, dll.

\subsection{Blok Diagram Sistem}

Pada sistem ini menggunakan microcontroller yaitu dengan Arduino uno R3 yang di gabungkan dengan modul ESP 8266. Sebagai pengontrol dari sistem kerja alat ini menggunakan sensor DHT22, Lux sensor, dan sensor Ph meter. Sistem ini bekerja dengan sebuah sensor DHT22 yang membaca nilai kelembaban dengan nilai sektar lebih dari 50\% dan suhu dari ruangan yang di tempati tanaman dengan nilai $20^{\circ} \mathrm{C}-30^{\circ} \mathrm{C}$, sensor Lux yang membaca nilai banyaknya cahaya dengan rentan pencahayaan sekitar 10-30 \% dan sensor Ph meter yang medeteksi nilai ph dengan rentan ph tanah berkisar 7-7,5. lalu pada sistem ini DFplayer bekerja sebagai output notifikasi. Data tersebut di olah oleh mikrokontroller Arduino R3 lalu data tersebut di kirimkan melalui modul ESP8266 ke dalam database dan akan di baca melalui web monitoring. Proses kerja pada alat ini di tunjukkan pada Gambar 1 


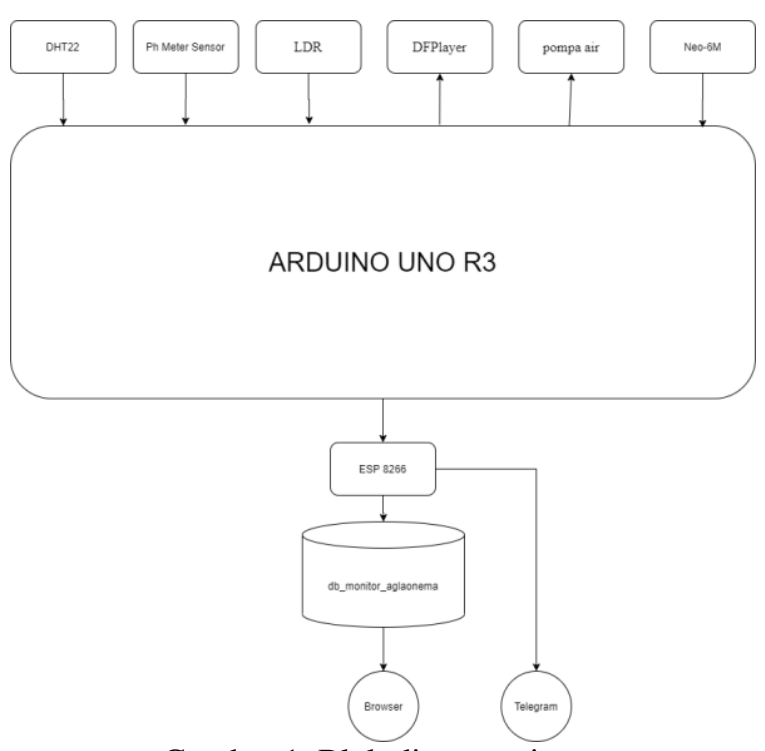

Gambar 1. Blok diagram sistem

\subsection{Flowchart Sistem}

Flowchart sistem ini menjelaskan proses berjalananya aplikasi seperti ditunjukkan pada Gambar 2.

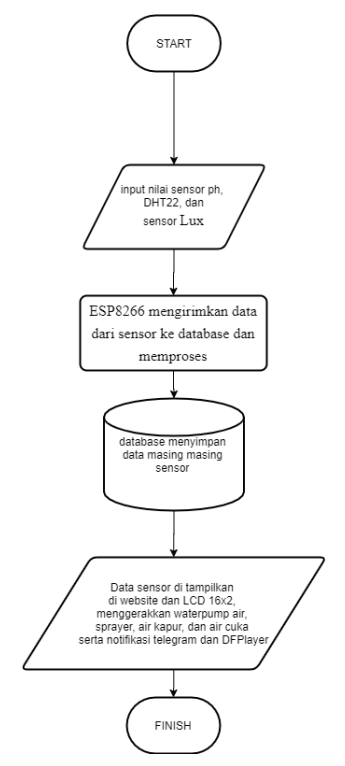

Gambar 2. Flowchart Sistem

Saat program di jalankan maka semua sensor dan modul akan di inisialisasi, sensor dan modul akan membaca kondisi dan nilai yang terbaca. Nilai dan kondisi akan di proses untuk menjalankan actuator dan akan di kirim serta di simpan ke database dengan perantara esp8266, data yang telah di simpan di database akan di tampilkan di web monitoring. Untuk data monitoring perhari akan di kirim melalui telegram, serta jika terjadi hal yang tidak di inginkan seperti pencurian maka bisa request lokasi tanaman melalui telegram. Actuator beserta modul akan membaca nilai sensor, aktuator dan modul akan berjalan sesuai kondisi nilai dari sensor.

\subsection{Flowchart Alat}

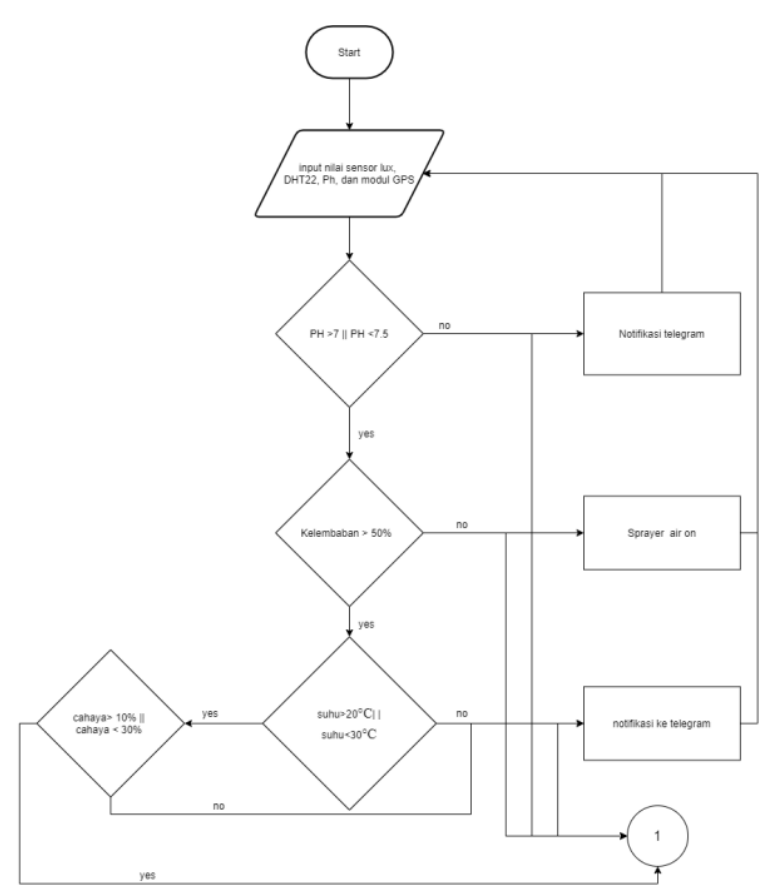

Gambar 3. Flowchart Alat

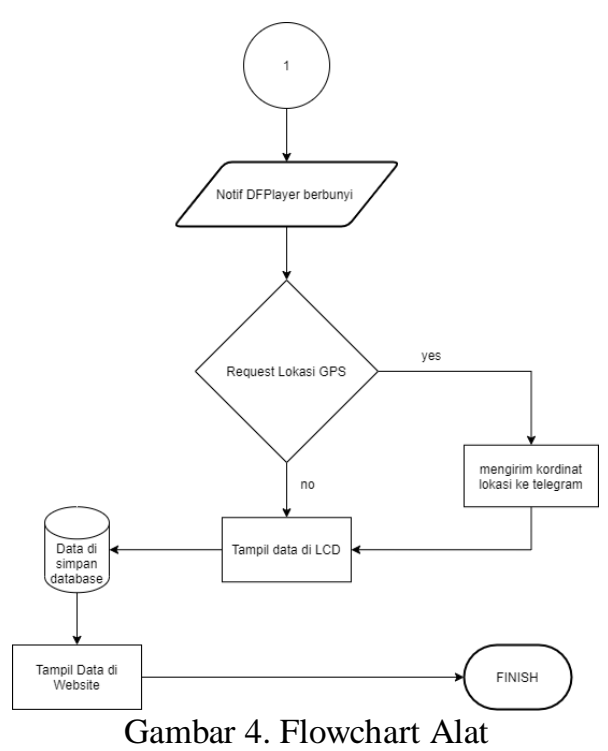

Pada kondisi program start maka semu sensor dan modul akan di inisialisasi setelah itu data yang di kirim ph meter akan di cek apakah ph nya antara 77,5 jika tidak notifikasi Telegram akan muncul, jika iya maka akan berlanjut ke kondisi cek kelembapan. Apakah kelembapan lebih dari 50\%, jika kondisi tidak terpenuhi maka sprayer air akan menyemprot dan notif DFPlayer akan berbunyi, jika terpenuhi maka berlanjut ke kondisi suhu. Apakah suhu lebih dari $20^{\circ} \mathrm{C}$ kurang dari $30^{\circ} \mathrm{C}$, jika kondisi tidak terpenuhi maka notif DFPlayer akan berbunyi, jika terpenuhi akan lanjut ke kondisi intensitas cahaya Apakah intensitas cahaya lebih dari $10 \%$ kurang dari $30 \%$, jika kondisi tidak terpenuhi maka notif DFPlayer akan berbunyi, jika kondisi terpenuhi maka 
notif DFPlayer akan berbunyi. Ada kondisi lagi dengan modul gps, di sini aka nada sebuah kondisi apakah ada request ke modul GPS jika iya maka modul gps akan mengirimkan lokasi via telegram dan notifikasi DFPlayer

\subsection{Flowchart Web}

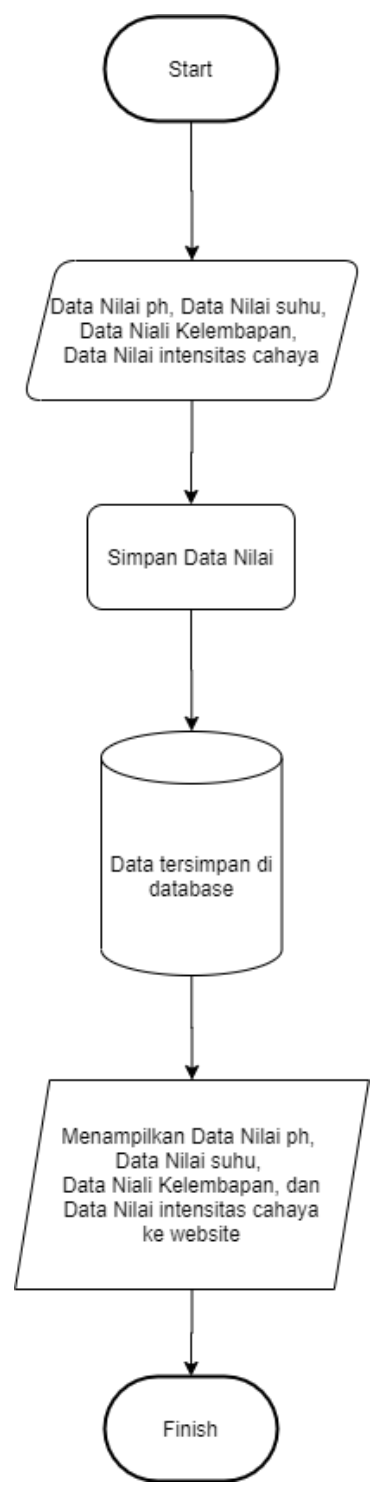

Gambar 5. Flowchart Web

Saat program berjalan maka semua data pada sensor akan di ambil dengan perantara NodeMCU ESP8266, setelah itu data akan di simpan pada database. Setelah data tersimpan data akan di ambil dan di tampilkan ke dalam web monitoring.

\section{HASIL DAN PEMBAHASAN}

\subsection{Hasil Implementasi}

Hasil immplementasi Penerapan Iot (Internet of Thing) Smart Flower Container Pada Tanaman Hias Aglaonema Berbasis Arduino, yang dirancang yaitu meliputi. Implementasi website monitoring, notifikasi telegram dan implementasi perangkat keras.

\subsection{Halaman Dashboard}

Halaman Dashboard adalah halaman yang berfungsi untuk menampilkan halaman utama pada website yang dibuat. Halaman utama pada website yang dibuat terdiri dari fitur penampil nilai sensor secara realtime, grafik dari nilai tiap sensor dan tombol link ke halaman monitoring.

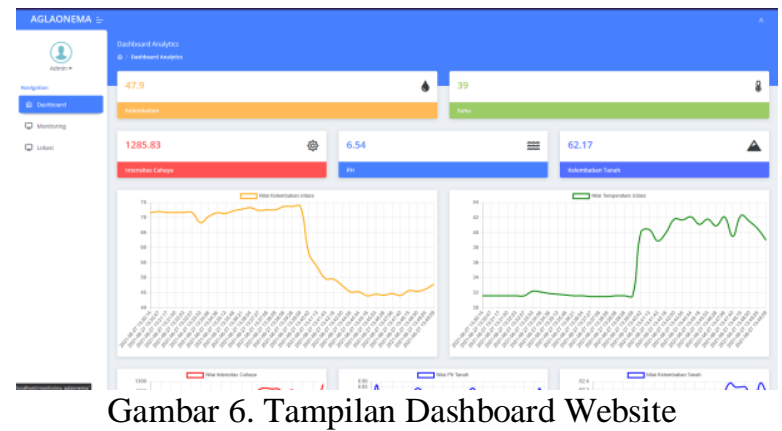

\subsection{Halaman Monitoring}

Halaman Monitoring adalah halaman yang berfungsi untuk menampilkan nilai yang ada pada sensor sesuai dengan waktu dan tanggal. Halaman ini terdiri dari 2 fitur yaitu fitur pencarian dan fitur navigasi halaman. Tampilan halaman monitoring pada penelitian ini ditunjukkan pada Gambar 7.

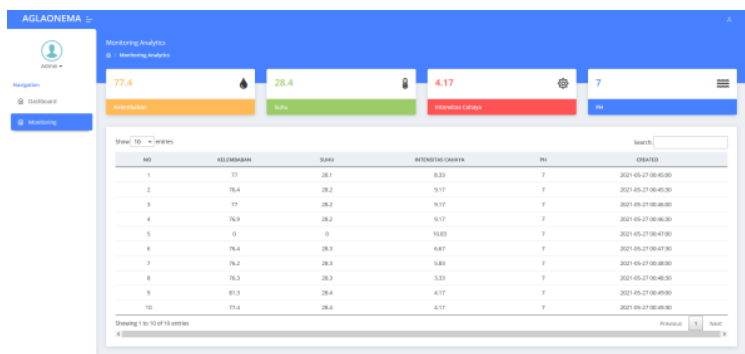

Gambar 7. Implementasi Halaman Monitoring.

\subsection{Halaman Lokasi}

Halaman lokasi adalah halaman yang berfungsi untuk menampilkan nilai dari longitude dan latitude yang di kirimkan dari modul GPS, pada halaman ini terdapat button yang akan terhubung ke google maps dan akan menampilkan nilai sesuai longitude dan latitude terbaru.

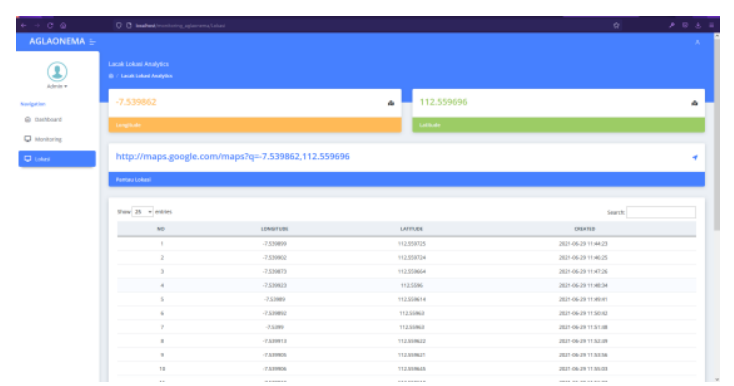

Gambar 8. Implementasi Halaman Lokasi. 


\subsection{Pengujian Website}

Pengujian website dilakukan untuk mengetahui fungsional fitur - fitur yang berjalan pada browser. Pada penelitian ini browser yang digunakan yaitu Mozilla Firefox, Google Chrome, dan Microsoft Edge yang terbaru. Pengujian website dilakukan untuk melakukan monitoring terhadap brankas. Pengujian yang dilakukan pada penelitian ini adalah sebagai berikut :

Tabel 1. Pengujian Website

\begin{tabular}{|c|c|c|c|c|}
\hline No & $\begin{array}{c}\text { Fungsi } \\
\text { Yang } \\
\text { Diuji } \\
\end{array}$ & $\begin{array}{l}\text { Google } \\
\text { Chrome }\end{array}$ & $\begin{array}{l}\text { Mozilla } \\
\text { Firefox }\end{array}$ & $\begin{array}{c}\text { Microsoft } \\
\text { Edge }\end{array}$ \\
\hline 1 & Login & $\checkmark$ & $\checkmark$ & $\checkmark$ \\
\hline \multirow[t]{6}{*}{2} & Halaman Dashboard & $\checkmark$ & $\checkmark$ & $\checkmark$ \\
\hline & $\begin{array}{l}\text { Tampilan Nilai sensor } \\
\text { berjalan secara } N o \\
\text { Reload }\end{array}$ & $\checkmark$ & $\checkmark$ & $\checkmark$ \\
\hline & $\begin{array}{l}\text { Tampilan grafik dari } \\
\text { nilai inputan sensor } \\
\text { DHT } 22 \text { (Kelembaban) }\end{array}$ & $\checkmark$ & $\checkmark$ & $\checkmark$ \\
\hline & $\begin{array}{l}\text { Tampilan grafik dari } \\
\text { nilai inputan sensor } \\
\text { DHT } 22 \text { (Suhu) }\end{array}$ & $\checkmark$ & $\checkmark$ & $\checkmark$ \\
\hline & $\begin{array}{l}\text { Tampilan grafik dari } \\
\text { nilai inputan sensor } \mathrm{PH}\end{array}$ & $\checkmark$ & $\checkmark$ & $\checkmark$ \\
\hline & $\begin{array}{l}\text { Tampilan grafik dari } \\
\text { nilai inputan sensor } \\
\text { Kelembaban Tanah } \\
\end{array}$ & $\checkmark$ & $\checkmark$ & $\checkmark$ \\
\hline \multirow[t]{5}{*}{3} & Halaman Monitoring & $\checkmark$ & $\checkmark$ & $\checkmark$ \\
\hline & $\begin{array}{l}\text { Tampilan Nilai sensor } \\
\text { berjalan secara No } \\
\text { Reload }\end{array}$ & $\checkmark$ & $\checkmark$ & $\checkmark$ \\
\hline & $\begin{array}{l}\text { Tabel Nilai Sensor No } \\
\text { Reload }\end{array}$ & $\checkmark$ & $\checkmark$ & $\checkmark$ \\
\hline & Search Box & $\checkmark$ & $\checkmark$ & $\checkmark$ \\
\hline & $\begin{array}{l}\text { Tombol Navigasi } \\
\text { Halaman }\end{array}$ & $\checkmark$ & $\checkmark$ & $\checkmark$ \\
\hline \multirow[t]{5}{*}{4} & Halaman Lokasi & $\checkmark$ & $\checkmark$ & $\checkmark$ \\
\hline & $\begin{array}{l}\text { Tampilan Nilai } \\
\text { longitude, latitude } \\
\text { berjalan secara } N o \\
\text { Reload }\end{array}$ & $\checkmark$ & $\checkmark$ & $\checkmark$ \\
\hline & $\begin{array}{l}\text { Tabel Nilai longitude, } \\
\text { latitude No Reload }\end{array}$ & $\checkmark$ & $\checkmark$ & $\checkmark$ \\
\hline & Search Box & $\checkmark$ & $\checkmark$ & $\checkmark$ \\
\hline & $\begin{array}{l}\text { Tombol Navigasi } \\
\text { Halaman }\end{array}$ & $\checkmark$ & $\checkmark$ & $\checkmark$ \\
\hline
\end{tabular}

Keterangan :

$\checkmark=$ Berjalan.

$\mathrm{x}=$ Tidak Berjalan .

Berdasarkan hasil pengujian website pada tabel 1 didapatkan hasil bahwa semua halaman dan setiap fitur yang ada pada wesbsite dapat berjalan dengan baik pada browser Mozilla Firefox, Google Chrome, dan Microsoft Edge versi terbaru.

\subsection{Implementasi Tampilan Notifikasi Telegram}

Implementasi tampilan pada notifikasi dan request telegram pada penelitian. Sistem berjalan dimulai dengan user mengirim request dengan cara salah satunya adalah mengetikan "/getNilaiSensor", sistem akan mengambil data dari sensor, selanjutnya sistem akan mengirim semua nilai sensor yang ada ke akun telegram user. Tampilan notifikasi telegram pada penelitian ini di tunjukkan pada Gambar 9.

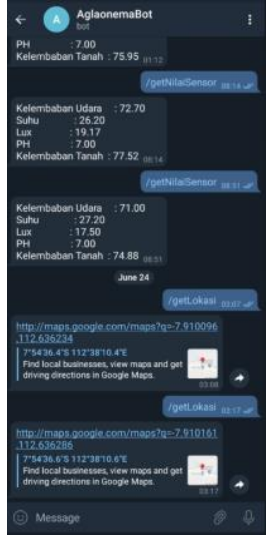

Gambar 9. Percobaan request telegram.

\subsection{Sensor Lux}

Pengujian sensor lux di lakukan dengan menggunakan lux meter dan melihat perbandingan dengan sensor BH1750, untuk membandingkan kedua nilainya dan di peroleh hasil sebagai berikut.

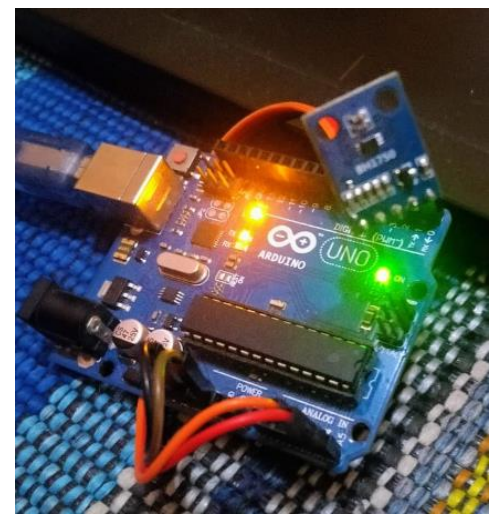

Gambar 10. Percobaan sensor Lux

Tabel 2. Pengujian Sensor BH1750

\begin{tabular}{|c|c|c|c|c|}
\hline \multirow{2}{*}{ No } & \multicolumn{2}{|c|}{ Lux } & \multirow{2}{*}{ Error } & \multirow{2}{*}{ Akurasi } \\
\cline { 2 - 3 } & $\begin{array}{c}\text { Sensor } \\
(\text { Lux) }\end{array}$ & $\begin{array}{c}\text { Lux Meter } \\
(\text { Lux) }\end{array}$ & & \\
\hline 1 & 1367.17 & 1303.4 & $4.9 \%$ & $95.1 \%$ \\
\hline 2 & 1385.5 & 1320.79 & $4.9 \%$ & $95.1 \%$ \\
\hline 3 & 1395.87 & 1347.9 & $3.6 \%$ & $96.4 \%$ \\
\hline 4 & 1356.72 & 1306.1 & $3.9 \%$ & $96.1 \%$ \\
\hline 5 & 1345.46 & 1295.3 & $3.9 \%$ & $96.1 \%$ \\
\hline
\end{tabular}

Pada pegujian sensor lux BH1750 di peroleh data dengan error rata-rata $4.0 \%$ dengan nilai error tertinggi sebesar $4.9 \%$ dan nilai error terendah $3.9 \%$, serta mendapat nilai akurasi rata-rata sebesar $96.0 \%$ dengan nilai akurasi tertinggi sebesar $96.4 \%$ dan nilai akurasi terendah $95.1 \%$.

\subsection{Sensor DHT22}

Pengujian sensor DHT22 di lakukan dengan menggunakan Hygrometer dan melihat perbandingan dengan sensor DHT22, untuk membandingkan kedua nilainya dan di peroleh hasil sebagai berikut. 


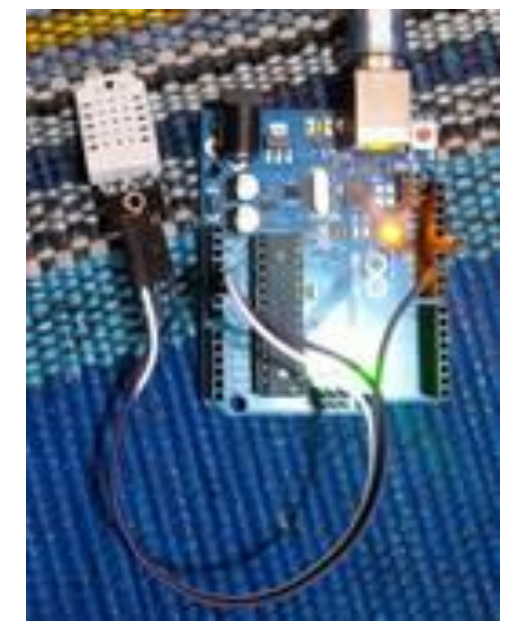

Gambar 11. Percobaan sensor DHT22

Tabel 3. Pengujian Suhu

\begin{tabular}{|c|c|c|c|c|}
\hline \multirow{2}{*}{ No } & \multicolumn{2}{|c|}{ Suhu } & \multirow{2}{*}{ Error } & \multirow{2}{*}{ Akurasi } \\
\cline { 2 - 5 } & Sensor $\left({ }^{\circ} \mathbf{C}\right)$ & Termometer $\left({ }^{\circ} \mathbf{C}\right)$ & & \\
\hline 1 & 26.1 & 25 & $4.4 \%$ & $95.6 \%$ \\
\hline 2 & 26.3 & 25 & $5.2 \%$ & $94.8 \%$ \\
\hline 3 & 26.4 & 25 & $5.6 \%$ & $94.4 \%$ \\
\hline 4 & 26.4 & 25 & $5.6 \%$ & $94.4 \%$ \\
\hline 5 & 26.4 & 25 & $5.6 \%$ & $94.4 \%$ \\
\hline
\end{tabular}

Pada pegujian suhu pada sensor DHT22 di peroleh data dengan error rata-rata $5.0 \%$ dengan nilai error tertinggi sebesar $5.6 \%$ dan nilai error terendah $4.4 \%$, serta mendapat nilai akurasi rata-rata sebesar $95.0 \%$ dengan nilai akurasi tertinggi sebesar $95.6 \%$ dan nilai akurasi terendah $94.4 \%$.

Tabel 4. Pengujian Kelembaban

\begin{tabular}{|c|c|c|c|c|}
\hline \multirow{2}{*}{ No } & \multicolumn{2}{|c|}{ Kelembaban } & \multirow{2}{*}{ Error } & \multirow{2}{*}{ Akurasi } \\
\cline { 2 - 3 } & Sensor(\%) & Hygrometer(\%) & & \\
\hline 1 & 80.9 & 76 & $6.4 \%$ & $93.6 \%$ \\
\hline 2 & 81.1 & 77 & $5.3 \%$ & $94.7 \%$ \\
\hline 3 & 81.1 & 77 & $5.3 \%$ & $94.7 \%$ \\
\hline 4 & 80.8 & 76 & $6.3 \%$ & $93.7 \%$ \\
\hline 5 & 80.8 & 76 & $6.3 \%$ & $93.7 \%$ \\
\hline
\end{tabular}

Pada pegujian kelembaban pada sensor DHT22 di peroleh data dengan error rata-rata $6.5 \%$ dengan nilai error tertinggi sebesar $8.0 \%$ dan nilai error terendah $5.2 \%$, serta mendapat nilai akurasi rata-rata sebesar $93.5 \%$ dengan nilai akurasi tertinggi sebesar $94.8 \%$ dan nilai akurasi terendah $92.0 \%$.

\subsection{Sensor $\mathbf{P H}$}

Pengujian sensor PH di lakukan dengan menggunakan soil $\mathrm{PH}$ meter dan melihat perbandingan dengan sensor $\mathrm{PH}$, untuk membandingkan kedua nilainya dan di peroleh hasil sebagai berikut.

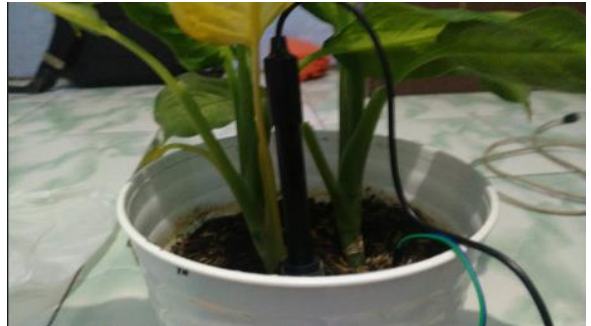

Gambar 12. Percobaan sensor Ph

Tabel 5. Pengujian PH

\begin{tabular}{|c|c|c|c|c|}
\hline \multirow{2}{*}{ No } & \multicolumn{2}{|c|}{ PH } & \multirow{2}{*}{ Error } & \multirow{2}{*}{ Akurasi } \\
\cline { 2 - 3 } & Sensor & Ph Meter & & \\
\hline 1 & 6.78 & 7 & $3.1 \%$ & $96.9 \%$ \\
\hline 2 & 6.8 & 7 & $2.9 \%$ & $97.1 \%$ \\
\hline 3 & 6.68 & 7 & $4.6 \%$ & $95.4 \%$ \\
\hline 4 & 6.54 & 7 & $6.6 \%$ & $93.4 \%$ \\
\hline 5 & 6.32 & 7 & $9.7 \%$ & $90.3 \%$ \\
\hline
\end{tabular}

Pada pegujian pada sensor $\mathrm{Ph}$ di peroleh data dengan error rata-rata $5.8 \%$ dengan nilai error tertinggi sebesar $9.7 \%$ dan nilai error terendah $2.9 \%$, serta mendapat nilai akurasi rata-rata sebesar $94.2 \%$ dengan nilai akurasi tertinggi sebesar $97.1 \%$ dan nilai akurasi terendah $90.3 \%$.

\subsection{Modul GPS Neo 6}

Pengujian Modul GPS Neo 6 yang dilakukan pada penelitian ini adalah sebagai berikut :

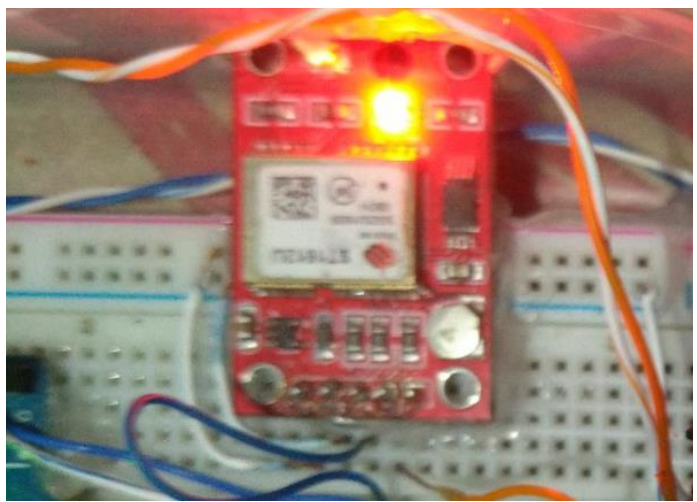

Gambar 13. Percobaan sensor Ph

Tabel 6. Pengujian Modul GPS Neo 6m

\begin{tabular}{|c|c|l|l|l|l|l|l|l|}
\hline \multirow{2}{*}{ No } & \multicolumn{2}{|c|}{ Keluaran Sensor } & \multicolumn{2}{|c|}{ Google Maps } & $\begin{array}{c}\text { Error } \\
\text { latitude }\end{array}$ & $\begin{array}{c}\text { Akurasi } \\
\text { latitude }\end{array}$ & $\begin{array}{c}\text { Error } \\
\text { longitude }\end{array}$ & $\begin{array}{c}\text { Akurasi } \\
\text { longitude }\end{array}$ \\
\cline { 2 - 9 } & Latitude & Longitude & Latitude & Longitude & & & & \\
\hline 1 & -7.90999 & 112.6362 & -7.91004 & 112.6362 & $9.9 \%$ & $90.1 \%$ & $0 \%$ & $100 \%$ \\
\hline 2 & -7.91013 & 112.6362 & -7.91004 & 112.6362 & $1 \%$ & $99 \%$ & $0 \%$ & $100 \%$ \\
\hline 3 & -7.91013 & 112.6362 & -7.91004 & 112.6362 & $1 \%$ & $99 \%$ & $0 \%$ & $100 \%$ \\
\hline 4 & -7.91013 & 112.6362 & -7.91004 & 112.6362 & $1 \%$ & $99 \%$ & $0 \%$ & $100 \%$ \\
\hline 5 & -7.9101 & 112.6362 & -7.91004 & 112.6362 & $1 \%$ & $99 \%$ & $0 \%$ & $100 \%$ \\
\hline
\end{tabular}




\subsection{NodeMCU ESP8266}

Dilakukan pengujian terhadap NodeMCU yang merupakan microcontroller yang dapat terhubung ke wifi. Berikut hasil dari pengujian NodeMCU.

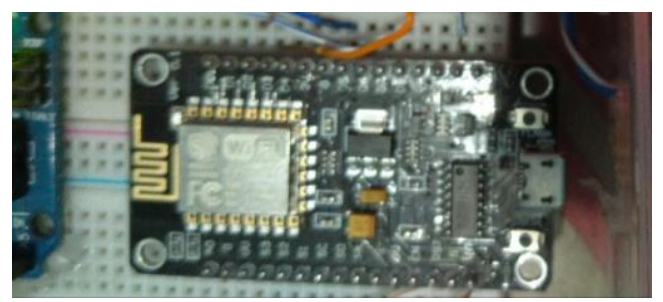

Gambar 14. Percobaan ESP8266

Tabel 7. Pengujian ESP8266

\begin{tabular}{|c|c|c|c|}
\hline \multirow[b]{2}{*}{ NO } & \multicolumn{2}{|c|}{ Waktu } & \multirow[b]{2}{*}{$\begin{array}{l}\text { Delay } \\
\text { (Detik) }\end{array}$} \\
\hline & $\begin{array}{c}\text { Waktu } \\
\text { pengiriman }\end{array}$ & $\begin{array}{l}\text { Waktu Tampil } \\
\text { di Web }\end{array}$ & \\
\hline 1 & 03:10:00 & 03:10:10 & 10 \\
\hline 2 & $03: 10: 16$ & $03: 10: 26$ & 10 \\
\hline 3 & $03: 10: 33$ & $03: 10: 43$ & 10 \\
\hline 4 & $03: 10: 50$ & 03:11:00 & 10 \\
\hline 5 & 03:11:06 & 03:11:16 & 10 \\
\hline
\end{tabular}

\subsection{Kelembaban Tanah}

Pengujian sensor Soil Moisture di lakukan dengan menggunakan alat ukur kelembaban tanah dan melihat perbandingan Soil Moisture, untuk membandingkan kedua nilainya dan di peroleh hasil sebagai berikut.

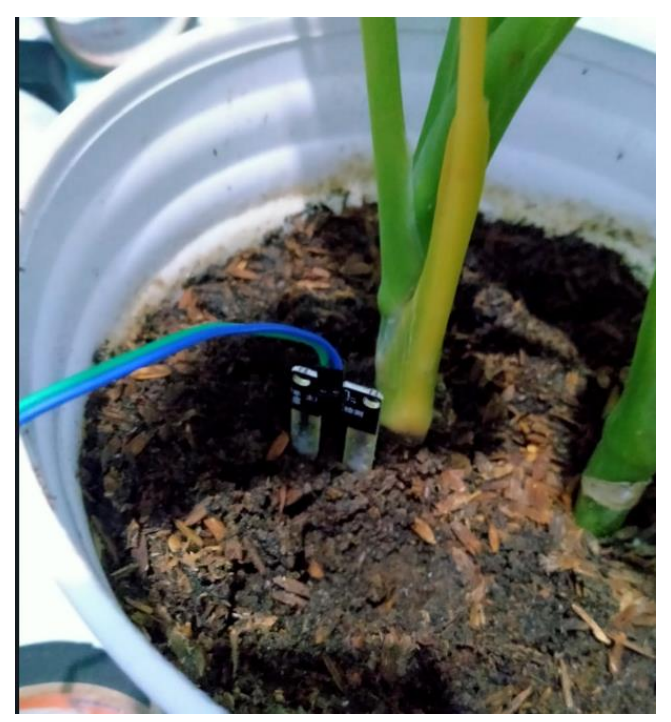

Gambar 15. Percobaan Soil Moisture

Tabel 8. Pengujian Soil Moisture

\begin{tabular}{|c|c|c|c|c|}
\hline \multirow{2}{*}{ No } & \multicolumn{2}{|c|}{ Soil Moisture } & \multirow{2}{*}{ Alat Soil } \\
\cline { 2 - 3 } & Sensor(\%) & $\begin{array}{c}\text { Alaisture } \\
\text { Moister } \\
\text { Meter(\%) }\end{array}$ & Akurasi \\
\hline 1 & 61 & 60 & $1.7 \%$ & $98.3 \%$ \\
\hline 2 & 60 & 60 & $0.0 \%$ & $100.0 \%$ \\
\hline 3 & 61.5 & 61 & $0.8 \%$ & $99.2 \%$ \\
\hline 4 & 70.2 & 70 & $0.3 \%$ & $99.7 \%$ \\
\hline 5 & 75.6 & 75 & $0.8 \%$ & $99.2 \%$ \\
\hline
\end{tabular}

Pada pegujian pada sensor Kelembaban Tanah di peroleh data dengan error rata-rata $0.4 \%$ dengan nilai error tertinggi sebesar $1.7 \%$ dan nilai error terendah $0.0 \%$, serta mendapat nilai akurasi rata-rata sebesar $99.6 \%$ dengan nilai akurasi tertinggi sebesar $100 \%$ dan nilai akurasi terendah $98.3 \%$.

\section{KESIMPULAN DAN SARAN \\ 5.1. Kesimpulan}

Setelah dilakukan perancangan monitoring perawatan ikan cupang maka dapat ditarik kesimpulan sebagai berikut:

1. Berdasarkan hasil pengujian fungsional menunjukkan hasil 100\%, artinya sistem yang telah dilakukan dapat disimpulkan bahwa sistem monitoring dan perawatan Tanaman Aglaonema dapat bekerja dengan baik.

2. Penambahan Modul GPS dalam system monitoring tanaman aglaonema dapat memantau lokasi tanaman jika terjadi pencurian, dengan akurasi data lokasi yang cukup akurat dengan nilai akurasi rata-rata 99\% dengan persentase error $1 \%$.

3. Berdasarkan hasil pengujian dari sensor DHT22 memiliki akurasi yang cukup akurat, dengan nilai akurasi suhu rata-rata sebesar $95.0 \%$ serta nilai akurasi kelembaban rata-rata sebesar $93.5 \%$.

4. Berdasarkan hasil pengujian pada browser, aplikasi dapat berjalan dengan baik pada web browser Google Chrome Versi 91.0.4472.10, Mozilla Firefox Versi 89 dan Microsoft Edge Versi 11.0.13. semua fungsi dihalaman utama sepertyi panel data, atau tabel, grafik, dan tampilan logout berfungsi dengan baik serta semua responsive dari aplikasi dan alat bisa berjalan dengan baik.

\subsection{Saran}

Dari hasil penelitian yang dilakukan oleh penulis, maka penulis menyarankan untuk pengembangan penlitian sebagai berikut:

1. Dalam penelitian ini dapat di kembangkan dengan cara menambahkan lagi feature keamanan seperti sensor getar dan sensor perpindahan.

2. Dapat dikembangkan website yang lebih baik untuk pengembangan selanjutnya, bisa menggunakan android untuk memantau perkembangan kondisi Tanaman Aglaonema.

\section{DAFTAR PUSTAKA}

[1] Tareh Rozzaq Adzdziqri, Yosep Agus Pranoto, Deddy Rudhistiar (2021) "Implementasi Iot (Internet Of Things) Pada Rumah Budidaya Jamur Tiram Puth". https://ejournal.itn.ac.id/index.php/jati/article/ view/3306/2627. (1, Maret 2021)

[2] Miko Andrianto (2019) "Penerapan Iot Pada Perawatan Tanaman Di Dalam Rumah". https://ejournal.itn.ac.id/index.php/jati/article/ view/627/581. ( 1, Maret 2019).

[3] Desvianty Ayu Wahyudi, Suryo Adi Wibowo, Renaldi Primaswara P (2021) "Rancang 
Bangun Sistem Padi Aquaponic Berbasis Iot (Internet of Things)". https://ejournal.itn.ac.id/index.php/jati/article/ view/3271/2592 (1, Maret 2021)

[4] Shaifany Fatriana Kadir (2019) penelitian dengan judul "Mobile Iot (Internet of Things) Untuk Pemantauan Kualitas Air Habitat Ikan Hias Pada Akuarium Menggunakan Metode Logika Fuzzy". https://ejournal.itn.ac.id/index.php/jati/article/ view/1394/1248. (1, Maret 2019)

[5] Joseph Dedy Irawan, Sonny Prasetio, dan Suryo Adi (2016), "Pengembangan Kunci Elektronik Menggunakan RFID Dengan Sistem Iot". https://lppm.itn.ac.id/webmin/assets/uploads/lj /LJ201701200010.pdf. (2, September 2016)

[6] Wahyu Adi Prayitno, Adharul Muttaqin, dan Dhanial Syauqy (2017), "Sistem Monitoring Suhu, Kelembaban, dan Pengendali
Penyiraman Tanaman Hidroponik menggunakanBlynk Android". https://jptiik.ub.ac.id/index.php/jptiik/article/view/87/46. (4, April 2017)

[7] Ade Salimah, Yayat Rochayat Suradinata dan Fiki Fadila (2010), "Respons Pertumbuhan Dan Kualitas Tiga Kultivar Aglaonematerhadap Kompetisi Media Tumbuh Arang Sekam, Cocopeat Dan Zeolit Serta Zpt Sitokinin”. http://pustaka.unpad.ac.id/wpcontent/uploads/2016/03/Jurnal-ResponsPertumbuhan-Dan-Kualitas-Tiga-Kultivar.pdf (3, Agustus 2010)

[8] Afriantoni, dan Ery Safrianti (2020), "Prototype Smart Greenhouse Untuk Tanaman Aglaonema Dengan Sistem Monitoring Berbasis IoT". https://jom.unri.ac.id/index.php/JOMFTEKNI K/article/viewFile/28618/27586. (2 juni 2020) 